KEMAS 15(1)(2019) 81-88
Jurnal Kesehatan Masyarakat

\title{
The Correlation between Hearing Loss and the Quality of Life of Workers Exposed to the Noise in the Textile Industry
}

\author{
Sumardiyono ${ }^{1 \llbracket}$, Reni Wijayanti ${ }^{1}$, Hartono ${ }^{2}$, Ari Probandari ${ }^{1}$ \\ ${ }^{1}$ Department of Public Health, Faculty of Medicine, Sebelas Maret University, Surakarta, Indonesia. \\ ${ }^{2}$ Department of Physiology, Faculty of Medicine, Sebelas Maret University, Surakarta, Indonesia.
}

\begin{tabular}{l} 
Article Info \\
\hline Article History: \\
Submitted February 2019 \\
Accepted July 2019 \\
Published July 2019 \\
\hline Keywords: \\
Environmental Health \\
Risk Analysis, Lead, \\
Riverside, Well water \\
\hline DOI \\
https://doi.org/10.15294/ \\
kemas.v15i1.18124
\end{tabular}

\section{Introduction}

In general, quality of life is perceived related to wellness. Persons who have high quality of life will be perceived of achieving wellness and vice versa. World Health Organization (WHO) defines the quality of life as an individual perception on their position in life within the context of their culture and value systems in relation to aim, expectation, standard, and worries (World Health Forum, 1996). Quality of life is a concept which consists of values related to social, environment, psychological, and physical aspects (Theofilou, 2013)making its measurement and incorporation into scientific study difficult. This is a theoretical paper regarding the definition and measuring of quality of life. The search strategy included a combination of key words 'quality of life', 'definition of QoL' as well as 'measuring QoL' in titles using Medline and Google Scholar databases. Quality of life is a complex, multifaceted construct that requires multiple approaches from different theoretical angles. Scientists from the various disciplines of social science are encouraged to exploit the strengths of other's contributions in a collaborative effort. A thorough understanding of subjective well-being requires knowledge of how objective conditions influence people's evaluations of their lives. Similarly, a complete understanding of objective indicators and how to select them requires that we understand

\footnotetext{
$\triangle$ Correspondence Address:

Department of Public Health, Faculty of Medicine, Sebelas Maret University, Surakarta

Email : sumardiyonoadi@gmail.com

pISSN 1858-1196 eISSN 2355-3596
} 
people's values, and have knowledge about how objective indicators influence people's experience of well-being." (Theofilou, 2013.

Numerous studies on the quality of life have been conducted, including a study by Kim et al. that focus on the relationship between daily life situation of patients with chronic stroke and the quality of life, particularly mobility and social cognitive dimensions (Kim, Kim, \& Kim, 2014). A research by Serra et al. among elderly showed a relationship between six minutes walking test (6WMT) and the quality of life (Serra et al., 2015). However, there was no relationship between 6WMT and the dimensions of emotional role, mental health, and vitality. A research by Hong et al. found that quality of life decreased significantly among people with osteoarthritis (Hong, Han, Shin, \& Chun, 2016). A study about quality of life in Indonesia had been conducted by Rahmani et al. that showed the relationship between 6WMT and quality of life of the patients at Hasan Sadikin Hospital, Bandung (Rahmani, Erwinanto, \& Andean, 2015). The findings from Zainuddin et al. showed that stress was related to the quality of life among type 2 diabetes mellitus patients at Arifin Achmad Hospital, Pekanbaru (Zainuddin, Utomo, \& Herlina, 2015).

Based on the previous studies, we found that quality of life has been studied in various types of patients and among elderly. However, there is lack of evidence about the quality of life among workers who received hazards from their working environment such as noise. Nada et al. stated that high-level noise from textile industry could affect hearing function among workers. The progressive hearing loss is one of the chronic problems which potentially influence the quality of life among workers (Nada, Ebraheem, \& Sheta, 2014).

Our study aimed to observe the relationship between hearing loss with the quality of life among workers in the textile industry. The findings would benefit the development of model to control noise as a prevention to hearing loss so that the quality of life would be better. The findings would contribute to efforts to improve the safety and health of workers in the textile industry.

Methods
The study design was a cross-sectional study to analyze the relationship between hearing loss and quality of life among workers in the textile industry who received noise in their working environment. The sampling technique was simple random sampling among workers in Iskandar Indah Printing Textile Surakarta Company, Indonesia. The inclusion criteria were female worker, had work for more than a year, and aged between 20-50 years old. The sample size was determined using sample size formula for correlative analysis by Hulley et al. with $\mathrm{Z}_{\alpha(5 \%)}=1.96, \mathrm{Z}_{\beta(10 \%)}=1.28$. The value of $r$ was defined using a pilot study $(r=0.227)$. An online software from Clinical \& Translational Science Institute (Hulley, Cummings, Browner, Grady, \& Newman, 2013) was used to finally get $\mathrm{n}=200$ subjects.

This research used four instruments. First, the questionnaire on demographic characteristics of workers. Second, the ShortForm Health Survey (SF-36) to assess the quality of life of workers. SF-36 had been validated among general population and other subpopulation (Ware \& Sherbourne, 2012). The third instrument was height and weight scale to measure body mass index (BMI), and the last instrument was audiometry which was calibrated to measure the level of hearing loss.

The data were analyzed using IBM Statistics software version 23. Descriptive analysis used minimal, maximal, and median value. In order to analyze the bivariate relationship between hearing loss, demographic characteristics, and quality of life, we used Spearman's rank correlation coefficient. In order to study the size of the relationship between hearing loss and quality of life among the workers, we used Chi-Square Test.

Before the study was conducted, the respondents received information about the aim of the research. The respondents had been informed that their participation in the study is voluntary. When they were agree, they were asked to sign the informed consent form before the interview. All information from the interviews and measurements were used for the purpose of the study only and kept for its confidentiality. Ethical clearance of the study was obtained from the Ethics Committee of Dr. Moewardi Hospital/Faculty of Medicine 
Sebelas Maret University with letter No. 753/ VII/HREC/2017.

\section{Results and Discussion}

There were 200 respondents in the study. All of the subjects were women, Indonesian, and aged 25-30 years old. Average age of the subject was 42 years old. The age of the respondents when they started to work was 24.7 years. The body mass index was between $18.7 \mathrm{~kg} / \mathrm{m}^{2}$ to $29.9 \mathrm{~kg} / \mathrm{m}^{2}$ with average of 24.1 $\mathrm{kg} / \mathrm{m}^{2}$. All respondents did not smoke (100\%).

There were 106 workers (53\%) exposed to over than normal noise level in the weaving related units. Ninety-four people (47\%) who exposed to normal noise were working at the units of warehouse and office. The highest level of noise was $104 \mathrm{dBA}$ while the lowest level was $64.4 \mathrm{dBA}$ with average of $86.6 \mathrm{dBA}$. The sources of noise were from machines in the textile industry. The type of noise was the continuous one. The standard level of noise was $85 \mathrm{dBA}$ per 8 hours of working per day.

The working years of the respondents were between 2-23 years with average of 17.1 years. Forty-two workers (42\%) used cotton as the protection device. Meanwhile, the Occupational Safetyand Health Administration, United States Department of Labor considered that cotton was not a good hearing protection device (OSHA, 2018). The sources of noise in the work environment were weaving machines (614 units). The picture of the weaving machine at the time of the research is shown in Figure 1.

The textile industry was basically divided into three departments: spinning, weaving and printing. The spinning department worked with raw material of cotton or synthetic material and processed it into yarns. The weaving department processed the yarns into fabrics. The printing department processed the raw fabrics (the grey fabrics) into color fabrics or ready fabrics. The working hours were divided into three shifts: morning shift (7 am-3 pm), afternoon shift (3 $\mathrm{pm}-11 \mathrm{pm})$, and night shift (11 pm- $7 \mathrm{am})$. The change of shift was conducted in every week, starting from Monday. In a week, the workers who dealt with the machines of warping, sizing, cone, pallet, weaving, and warehouse units could work during morning, afternoon or night shift, meanwhile, the workers who worked with the machines of reaching, inspecting-folding, and office only worked in morning shift.

This research was conducted only among workers in morning shift. The respondents were workers at unit of weaving, cone, winding, warping, sizing, reaching, inspecting-folding, warehouse and office. The workers at the units of weaving, winding, cone, warping, inspectingfolding and ware house were mostly stand during their working hours, while the workers

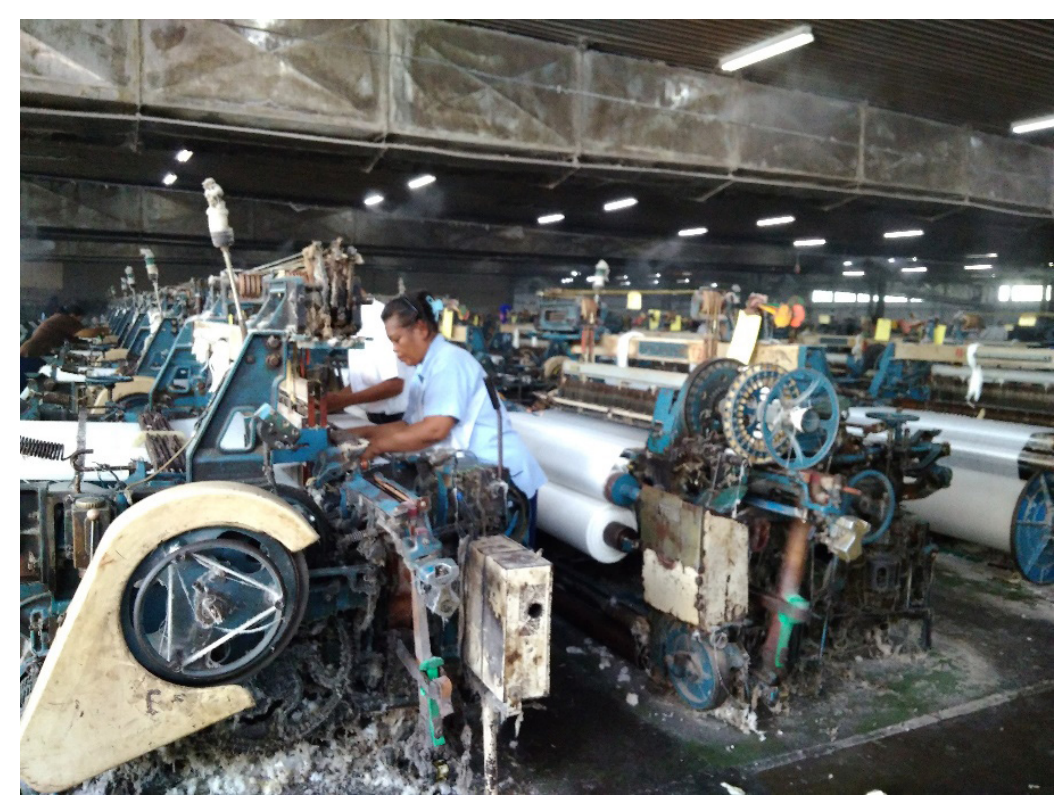

Figure 1. Weaving Machines 
at the reaching and office were usually sit in most of their time. The intensity of noise was measured on $10 \mathrm{am}, 1 \mathrm{pm}$ and $3 \mathrm{pm}$, and the results were assessed for Leq 8 working hours $\left(\mathrm{L}_{\text {Aeq, }, 8 \mathrm{~h}}\right)$.

Beside noise, we measured other working environment parameters such as level of dust, light intensity, mechanical vibration and heat stress. The level of dust was measured by low volume dust sampler, with the result of $0.29 \mathrm{mg} /$ $\mathrm{m}^{3}$ in average. The light intensity was measured by Luxmeter. The results showed the light intensity average was 163.3 lux. The mechanical vibration was measured by vibration meter; the results showed the average mechanical vibration was $2.14 \mathrm{~m} / \mathrm{s}^{2}$. Heat stress was measured by Area heat stress Monitor using the parameter of Web bulb Globe Temperature (WBGT). The result of average WBGT was $28.3^{\circ} \mathrm{C}$.

The hearing losses which were included in the study were both in the right ear or left ear. In this study, the level of hearing loss was measured by audiometry with the standard of conduction among the two ears at the frequency of $500 \mathrm{~Hz}, 1000 \mathrm{~Hz}, 2000 \mathrm{~Hz}$, and $4000 \mathrm{~Hz}$ in $\mathrm{dB}$ through headphone, which then was measured for its average (Beck et al., 2014) (AlAbri et al., 2016). The measurement of hearing loss was conducted in the morning at 6 to $8 \mathrm{am}$. The formula to calculate the average value of hearing loss of both ears was (monaural of the better ear x $5+$ monaural of the worst ear x 1 ) $/ 6$.

Based on The American SpeechLanguage-Hearing Association, the criteria of hearing loss is categorized as Normal (-10 to 15 $\mathrm{dB}$ ), Slight (16 to $25 \mathrm{~dB}$ ), Mild (26 to $40 \mathrm{~dB}$ ),
Moderate (41 to $55 \mathrm{~dB}$ ), Moderately Severe (56 to 70), Severe (56 to 90), and Profound (91 dB or more). Based on those criteria, we analyzed the hearing loss among 200 respondents descriptively. The findings showed that 6 workers (3\%) had moderately severe level, 44 workers (22\%) had moderate level, 130 workers (65\%) had mild level, and 20 workers (10\%) had slight level hearing loss (ASHA, 2018).

The category of quality of life use the one from Ware et al. as follows: the score of 100 for Perfect, 84 to 99 for Very Good, 61-83 for Good, 25-60 for Less, and score under 25 for Poor (Ware Jr, Snow, Kosinski, \& Gandek, 1993). In this study, we categorized the quality of life into two groups, the score of 61 or more for Good and the one less than 61 as Not Good. Our finding showed that among 200 respondents, there were 116 persons with Good Quality of Life (58\%), while the rest had Not Good quality of life ( 84 workers, $42 \%$ ).

The relationship between hearing loss and quality of life and its dimensions are shown in Table 1.

In Table 1, it is shown that the median value of hearing loss is categorized in Moderate/ Mild i.e. 26-40 dB. There was a statistically significant relationship between hearing loss and quality of life in all dimensions. The increase of hearing loss level was related to the decrease of quality of life. The size of risk of hearing loss to quality of life was measured by contingency coefficient test (C) as shown in Table 2.

Table 2 gives a description of the statistical test results which showed an effect between hearing loss and quality of life among workers.

Tabel 1. The relationship between Hearing loss and Quality of life $(n=200)$ in 2018

\begin{tabular}{|c|c|c|c|c|c|c|c|c|c|}
\hline $\begin{array}{l}\text { Indep endent } \\
\text { Variable }\end{array}$ & $\begin{array}{l}\text { Min } \\
(\mathrm{dB})\end{array}$ & $\begin{array}{l}\operatorname{Max} \\
(\mathrm{dB})\end{array}$ & $\begin{array}{l}\text { Median } \\
(\mathrm{dB})\end{array}$ & Dependent Variable & $\begin{array}{l}\text { Min } \\
(\%)\end{array}$ & $\begin{array}{l}\operatorname{Max} \\
(\%)\end{array}$ & $\begin{array}{l}\text { Median } \\
(\%)\end{array}$ & $r_{s}$ & $\mathrm{P}$ \\
\hline \multirow[t]{9}{*}{ Hearing loss } & 17.9 & 69.0 & 34.1 & Quality of life & 36.6 & 97.8 & 75.6 & -0.698 & $0.000^{*}$ \\
\hline & & & & Physical Functioning & 20.0 & 100.0 & 80.0 & -0.493 & $0.000^{*}$ \\
\hline & & & & Role-Physical & 25.0 & 100.0 & 75.0 & -0.501 & $0.000^{\star}$ \\
\hline & & & & Bodily Pain & 21.0 & 100.0 & 69.5 & -0.516 & $0.000^{*}$ \\
\hline & & & & General Health & 37.5 & 100.0 & 72.5 & -0.497 & $0.000^{*}$ \\
\hline & & & & Vitality & 20.0 & 100.0 & 67.5 & -0.527 & $0.000^{*}$ \\
\hline & & & & Social Functioning & 12.5 & 100.0 & 75.0 & -0.521 & $0.000^{*}$ \\
\hline & & & & Role-Emotional & 33.3 & 100.0 & 66.6 & -0.521 & $0.000^{*}$ \\
\hline & & & & Mental Health & 32.0 & 100.0 & 72.0 & -0.517 & $0.000^{*}$ \\
\hline
\end{tabular}

* significant at $\mathrm{p}<0.05(2$-tailed $)$ 
Tabel 2. The size of risk of hearing loss to quality of life in 2018

\begin{tabular}{lllllll}
\hline \multirow{2}{*}{ Hearing loss } & \multicolumn{2}{l}{ Quality of life } & & \multirow{2}{*}{$X^{2}$} & p & \multirow{2}{*}{$\mathrm{C}$} \\
\cline { 2 - 4 } & Not Good & Good & Total & & \\
\cline { 2 - 5 } & $\mathrm{n}(\%)$ & $\mathrm{n}(\%)$ & $\mathrm{n}(\%)$ & & & \\
\hline Moderately severe & $4(66.7)$ & $2(33.3)$ & $6(100)$ & 11.817 & 0.008 & 0.236 \\
Moderate & $23(52.3)$ & $21(47.7)$ & $44(100)$ & & & \\
Mild & $55(42.3)$ & $75(57.7)$ & $130(100)$ & & & \\
Slight & $2(10.0)$ & $18(90.0)$ & $20(100)$ & & & \\
\hline
\end{tabular}

${ }^{\star}$ significant at $\mathrm{p}<0.05$ (2-tailed)

Table 3. Relationship between demographic characteristics and quality of life in 2018

\begin{tabular}{|c|c|c|c|c|c|c|c|c|c|c|}
\hline Demographic characteristic & Min & Max & Median & Variable & & Min & Max & Median & $r_{s}$ & $\mathrm{p}$ \\
\hline Age (year) & 25 & 50 & 43.0 & \multirow{3}{*}{$\begin{array}{l}\text { Quality } \\
\text { life (\%) }\end{array}$} & \multirow{3}{*}{ of } & \multirow[t]{3}{*}{36.6} & \multirow[t]{3}{*}{97.8} & \multirow[t]{3}{*}{75.6} & -0.160 & $0.024^{*}$ \\
\hline $\operatorname{BMI}\left(\mathrm{kg} / \mathrm{m}^{2}\right)$ & 18.7 & 29.9 & 24.0 & & & & & & -0.126 & 0.076 \\
\hline Working period (years) & 2 & 23 & 19.5 & & & & & & -0.115 & 0.104 \\
\hline
\end{tabular}

${ }^{\star}$ significant at $\mathrm{p}<0.05(2$-tailed $)$

The size of risk between hearing loss to quality of life was $23.6 \%$ which meant that $76.4 \%$ of variation of quality of life was influenced by other factors. The other factors that was related to the decrease of quality of life were age, body mass index and working years. The relationship between the demographic characteristics and quality of life are shown in Table 3.

Table 3 shows the relationship between demographic characteristics and quality of life among workers. The increase of values of the demographic characteristics would decrease the quality of life, however, only age of the workers was shown as a significant variable. Referring to table 1 and 3, hearing loss and age had relationships with quality of life among the workers.

This research found a negative relationship between hearing loss and quality of life among the workers in the textile industry who suffered from noise level that was over the normal standard. The intensity of the noise would result in the increase of hearing loss. The workers with increased level of hearing loss would have lower quality of life. Hearing loss was related to all dimensions of quality of life, namely Physical Functioning, Role-Physical, Bodily Pain, General Health, Vitality, Social Functioning, Role-Emotional, and Mental Health.

Overexposure to noise could lead to irreversible disease. However, workers were always exposed to noise. A previous study by Afiah et al. in workers at automotive industry found a correlation between lack of knowledge, attitude and practice and noise-induced hearing loss which meant that there should be adequate efforts to prevent hearing loss among workers (Afiah, Farhan, \& Anita, 2017).

Noise-induced hearing loss has been reported in various industrial setting including mining industry which had over the normal noise level (94 dBA). It particularly happened at underground mining site (102 dBA) and underground workshop (103 dBA). The noise caused hearingloss in $36.7 \%$ workers; the hearing loss prevalence would increase by the increase of age (Chadambuka, Mususa, \& Muteti, 2013). Hearing loss was also found as a problem in the ceramic industry with the prevalence of slight and mild hearing loss of 44\% (Mehrparvar, Heidari, Sharifabadi, \& Javad, 2017). A study at textile industry setting in India found hearing loss among $39 \%$ of workers with exposure to noise at 87.3 dBA within 8-12 hours per day (Ranga, Yadav, Yadav, Yadav, \& Ranga, 2014). A research in Malaysia revealed that the cost of noise induces hearing loss (NIHL) has been a financial burden to the country, therefore the government of Malaysia developed a regulation to decrease the noise exposure in industrial setting (Noraita \& Aljunid, 2016). 
The relationship between hearing loss and quality of life had been studied by Carlsson et al. which revealed that severe and profound hearing loss were related to higher risk of anxiety and depression among general patients. The incidence of tinnitus and vertigo among patients with hearing loss had a strong negative correlation with quality of life (Carlsson et al., 2014). Another cause of hearing loss was the pesticide as founded in a study by de Sena et al. in Brazil. The study revealed hearing loss due to pesticide uses which decreased the quality of life among agricultural workers (de Sena, Vargas, \& Oliveira, 2013).

The relationship between hearing loss and quality of life was not shown among HIV patients. HIV treatment did not related to the decrease of quality of life. However, further research is needed to study the relationship between aging and quality of life of the patients (Duong, Torre, \& Springer, 2016).

Among the confounding variables, age was negatively associated with quality of life. A study regarding age and the quality of life by Campos et al. concluded that adults would have a better quality of life if they maintained their personal health and lack of depression. Women with lack of physical activity were prone to have lower quality of life. Hence, the older adult, if they could maintain their personal health, lack of depression and adequate physical activity, therefore their quality of life would be optimal (Campos, Ferreira, Vargas, \& Albala, 2014)a rapidly aging country suffering from large inequalities, the study of the quality of life (QOL. This is in conjunction with a study from Netuveli_\& Blane on the relationship between elderly, adaptation and resilience that are essentials to the quality of life. Two main factors to quality of life among elderly were dementia and depression (Netuveli \& Blane, 2008).

The demographic characteristics of BMI showed that $31.3 \%$ of the respondents with preobesity have Not-Good quality of life. However, the BMI and quality of life in this study did not show a statistically significant relationship. This finding differed with a study by Zhu et al. that revealed the difference in quality of life among the group with obesity level I and normal BMI, particularly in mental dimension. Furthermore,
$\mathrm{Zu}$ et al. also found that the group of thin BMI had lower quality of life compared to other groups, particularly in physical and mental dimension. Meanwhile, the group with obesity type II had lower quality of life in physical function (Zhu et al., 2015). Our findings also differed with a study by Søltoft et al. that used a sample of thin and obesity groups, which revealed a negative relationship between BMI and quality of life (Søltoft, Hammer, \& Kragh, 2009). The maximum quality of life is achieved at BMI $26.0 \mathrm{~kg} / \mathrm{m}^{2}$ among men and BMI 24.5 $\mathrm{kg} / \mathrm{m}^{2}$ among women. In accordance with this finding, the study by $\mathrm{Xu}$ et al. revealed a nonlinear relationship between BMI and quality of life. $\mathrm{Xu}$ et al. found the optimal quality of life will be achieved at BMI around $23 \mathrm{~kg} / \mathrm{m}^{2}$ for men and $24 \mathrm{~kg} / \mathrm{m}^{2}$ for women (Xu et al., 2015). A study by Rashidah et al. concluded that the increase of weight would decrease the quality of life among Melayu housewives. This was an evidence of the need to conduct an intervention program to improve quality of life among housewives (Rashidah, Suzana, Safiza, \& Azahadi, 2016).

The working period was not related to quality of life. The literature about the relationship between working years and quality of life among the workers in the textile industry is still scarce. We found only one study by von Bonsdorff et al. which concluded that working hours among men would decrease the quality of life due to lack of sleep duration, particularly in the dimension of physical function, vitality and general health. Furthermore, von Bonsdorff et al. also found that men with long working hours and normal sleeping duration were prone to have decrease in quality of life in elderly, particularly in the physical dimension (Von Bonsdorff et al., 2017)the combined effect of these two exposures on health-related quality of life (HRQoL.

The results of our study found that hearing loss was associated with decreased quality of life in workers of textile industry $\left(\mathrm{r}_{\mathrm{s}}=-\right.$ $0.698 ; \mathrm{p}=0.000)$. The the dimensions of quality of life which were associated with hearing loss were physical functioning $\left(r_{s}=-0.493 ; p=0.000\right)$, role-physical $\left(\mathrm{r}_{\mathrm{s}}=-0.501 ; \mathrm{p}=0.000\right)$, bodily pain $\left(r_{s}=-0.516 ; p=0.000\right)$, general health $\left(r_{s}=-\right.$ $0.497 ; \mathrm{p}=0.000)$, vitality $\left(\mathrm{r}_{\mathrm{s}}=-0.527 ; \mathrm{p}=0.000\right)$, 
social functioning $\left(\mathrm{r}_{\mathrm{s}}=-0.521 ; \mathrm{p}=0.000\right)$, roleemotional $\left(\mathrm{r}_{\mathrm{s}}=-0.521 ; \mathrm{p}=0.000\right)$, and mental health $\left(r_{s}=-0.517 ; p=0.000\right)$. Hearing loss caused a decrease in the quality of life by $23 \%$ while the remaining $76 \%$ was influenced by other factors such as age $(p=0.024)$. Therefore, this study concluded that factors which lead to decreased quality of life were hearing loss and age.

\section{Conclusions}

Hearing loss has a significant negative correlation with quality of life among workers in textile industry. The increase in hearing loss level would decrease the quality of life of the workers.

\section{AcknowledgEments}

The authors express gratitude to the head of Research and Community Empowerment Agency (LPPM) Sebelas Maret University for the support as well as the Director of PT. Iskandar Indah Printing Textile Surakarta for the permission to conduct the research.

\section{References}

Afiah, M. Z. R., Farhan, R. M., \& Anita, A. R. (2017). Predictors of Knowledge, Attitude and Practice of Noise Induced Hearing Loss among Workers in an Automotive Industry in Malaysia. Malaysian Journal of Medicine and Health Sciences, 13(1), 61-68. Retrieved from http://www.medic.upm.edu. my/upload/dokumen/2017050314451408_ MJMHS_Jan_2017_-_0011_Predictors_of_ Knowledge.pdf

Al-Abri, R., Al-Balushi, M., Kolethekkat, A., Bhargava, D., Al-Alwi, A., Al-Bahlani, H., \& Al-Garadi, M. (2016). The accuracy of IOS device-based uHear as a screening tool for hearing loss: A preliminary study from the middle East. Oman Medical Journal, 31(2), 142-145. https://doi.org/10.5001/ omj.2016.27

ASHA. (2018). Degree of Hearing Loss. Retrieved from https://www.asha.org/public/hearing/ degree-of-hearing-loss/

Beck, D. O., Miquelino, R., Ramos, F., Grasel, S., Ramos, F., Moraes, B. B. De, ... Paulo, S. (2014). Comparative study between pure tone audiometry and auditory steady-state responses in normal hearing subjects. Braz J Otorhinolaryngol, 80(1), 35-40. https://doi. org/10.5935/1808-8694.20140009

Campos, A. C. V., Ferreira, E. F. e., Vargas, A. M. D., \& Albala, C. (2014). Aging, Gender and Quality of Life (AGEQOL) study: Factors associated with good quality of life in older
Brazilian community-dwelling adults. Health and Quality of Life Outcomes, 12(1), 1-11. https://doi.org/10.1186/s12955-014-0166-4

Carlsson, P.-I., Hjaldahl, J., Magnuson, A., Ternevall, E., Edén, M., Skagerstrand, Å., \&, \& Jönsson, R. (2014). Severe to profound hearing impairment: quality of life, psychosocial consequences and audiological rehabilitation, 37(20), 1849-1856. https://doi.org/doi:10.31 09/09638288.2014.982833

Chadambuka, A., Mususa, F., \& Muteti, S. (2013). Prevalence of noise induced hearing loss among employees at a mining industry in Zimbabwe. African Health Sciences, 13(4), 899-906. https://doi.org/10.4314/ahs.v13i4.6

de Sena, T. R. R., Vargas, M. M., \& Oliveira, C. C. da C. (2013). Hearing care and quality of life among workers exposed to pesticides. Ciência \& Saúde Coletiva, 18(6), 1753-1761. https://doi.org/doi.org/10.1590/S141381232013000600026

Duong, N., Torre, P., \& Springer, G. (2016). Hearing Loss and Quality of Life (QOL) among Human Immunodeficiency Virus (HIV)Infected and Uninfected Adults. Journal of AIDS \& Clinical Research, 7(12), 1-6. https:// doi.org/10.4172/2155-6113.1000645

Hong, J. Y., Han, K., Shin, D. H., \& Chun, E. M. (2016). Quality of life analysis and smoking correlation in symptomatic spine osteoarthritis: A nationwide health survey analysis of an elderly population with EQ5D. PLoS ONE, 11(3), 1-10. https://doi. org/10.1371/journal.pone.0151315

Hulley, S. B., Cummings, S. R., Browner, W. S., Grady, D. G., \& Newman, T. B. (2013). Designing Clinical Research. (4, Ed.). Philadelphia: Lippincott Williams \& Wilkins.

Kim, K., Kim, Y. ., \& Kim, E. . (2014). Correlation between the Activities of Daily Living of Stroke Patients in a Community Setting and Their Quality of Life. J. Phys. Ther. Sci., 26, 417-419.

Mehrparvar, A. H., Heidari, F., Sharifabadi, M. S., \& Javad, M. (2017). Prevalence and Pattern of Noise-induced Hearing Loss in Tile and Ceramic Industry. International Journal of Occupational Hygiene, 9(2), 60-65.

Nada, E., Ebraheem, W. M., \& Sheta, S. (2014). Noise-induced hearing loss among workers in textile factory. The Egyptian Journal of Otolaryngology, 30, 243-248. https://doi. org/10.4103/1012-5574.138484

Netuveli, G., \& Blane, D. (2008). Quality of life in older ages. British Medical Bulletin, 85, 113126. https://doi.org/10.1093/bmb/ldn003 
Noraita, T., \& Aljunid, S. M. (2016). Direct and Indirect Cost of Noise Induced Hearing Loss among Manufacturing Industrial Workers in Malaysia. Malaysian Journal of Public Health Medicine, 16, 108-109.

OSHA. (2018). Regulations (Standards - 29 CFR), Hearing protection. Washington, DC. Retrieved from https://www.osha.gov/pls/ oshaweb/owadisp.show_document?p_ $\mathrm{id}=10664 \&$ p_table=STANDARDS

Rahmani, S., Erwinanto, E., \& Andean, R. (2015). Correlation between Six-Minutes' Walk Test and Quality of Life in Heart Failure Patients. Althea Medical Journal, 2(4), 469-473. https://doi.org/10.15850/amj.v2n4.629

Ranga, R. K., Yadav, S. P. S., Yadav, A., Yadav, N., \& Ranga, S. B. (2014). Prevalence of occupational noise induced hearing loss in industrial workers, 20(3), 115-118. https:// doi.org/10.4103/0971-7749.136848

Rashidah, A., Suzana, S., Safiza, M. N. ., \& Azahadi, O. . (2016). Health-Related Quality of Life among Overweight or Obese Malay Housewives in Klang Valley: A Baseline Study of a Community Intervention. Malaysian Journal of Public Health Medicine, 16, 75.

Serra, A. J., De Carvalho, P. D. T. C., Lanza, F., De Amorim Flandes, C., Silva, S. C., Suzuki, F. S., ... Silva, J. A. (2015). Correlation of sixminute walking performance with quality of life is domain- And gender-specific in healthy older adults. PLoS ONE, 10(2), 1-8. https:// doi.org/10.1371/journal.pone.0117359

Søltoft, F., Hammer, M., \& Kragh, N. (2009). The association of body mass index and health-related quality of life in the general population: data from the 2003 Health Survey of England Health Survey for England. Qual Life Res, 18, 1293-1299. https://doi.org/10.1007/s11136-009-9541-8

Theofilou, P. (2013). Quality of life: Definition and measurement. Europe's Journal of Psychology, 9(1), 150-162. https://doi.org/10.5964/ejop. v9i1.337

Von Bonsdorff, M. B., Strandberg, A., Von Bonsdorff, M., Törmäkangas, T., Pitkälä, K. H., \& Strandberg, T. E. (2017). Working hours and sleep duration in midlife as determinants of health-related quality of life among older businessmen. Age and Ageing, 46(1), 108112. https://doi.org/10.1093/ageing/afw178

Ware, J. E., \& Sherbourne, C. D. (2012). The MOS 36Item Short-Form Health Survey ( SF-36 ) I . Conceptual Framework and Item Selection. Medical Care, 30(6), 473-483.

Ware Jr, J. E., Snow, K. K., Kosinski, M., \& Gandek, B. (1993). SF-36 health survey: Manual and interpretation guide. Boston: Health Institute, New England Medical Center.

World Health Forum. (1996). What quality of life? World Health Organization. Retrieved from https://apps.who.int/iris/ handle/10665/54358

Xu, Y., Zhou, Z., Li, Y., Yang, J., Guo, X., Gao, J., ... Chen, G. (2015). Exploring the nonlinear relationship between body mass index and health-related quality of life among adults : a cross-sectional study in Shaanxi Province, China. Health and Quality of Life Outcomes, 1-9. https://doi.org/10.1186/s12955-0150347-9

Zainuddin, M., Utomo, W., \& Herlina. (2015). Hubungan Stres dengan Kualitas Hidup Penderita Diabetes Mellitus Tipe 2. JOM, 2(1), 890-898.

Zhu, Y., Wang, Q., Pang, G., Lin, L., Origasa, H., \& Wang, Y. (2015). Association between Body Mass Index and Health-Related Quality of Life: The " Obesity Paradox " in 21, 218 Adults of the Chinese General Population. PLoS ONE, 10(6), 1-13. https://doi. org/10.1371/journal.pone.0130613 